\title{
New Phenylethanoid Glycosides from Bacopa monniera
}

\author{
Ajit Kumar Chakravarty, ${ }^{a}$ Tapas Sarkar,${ }^{a}$ Takahisa Nakane, ${ }^{b}$ Nobuo Kawahara, ${ }^{b}$ and \\ Kazuo MASUdA ${ }^{*, c}$ \\ ${ }^{a}$ Indian Institute of Chemical Biology; Calcutta 700 032, India: ${ }^{b}$ National Institute of Health Sciences; $1-18-1$ Kamiyoga, \\ Setagaya-ku, Tokyo 158-8501, Japan: and ' Showa Pharmaceutical University; Machida, Tokyo 194-8543, Japan. \\ Received July 8, 2002; accepted October 1, 2002
}

Three new phenylethanoid glycosides, viz. monnierasides I-III (1-3) along with the known analogue plantainoside B were isolated from the glycosidic fraction of Bacopa monniera. Their structures were elucidated mainly on the basis of two dimensional (2D) NMR spectral analyses.

Key words Bacopa monnxiera; Scrophulariaceae; phenylethanoid glycoside; monnieraside I; 2D NMR

The reputation of Bacopa monniera WETTST. as a nervine tonic is well known in Indian traditional medicine. ${ }^{1)}$ Recent pharmacological studies indeed confirmed the activity. ${ }^{2-4)}$ It was also confirmed that the activity was due to the glycosides present in the alcoholic extract of the plant. Because of the presence of a large number of glycosidic constituents in the extract as an intimate mixture, two groups of workers could isolate and characterize only a part of the constituents. ${ }^{5-10)}$ In view of the increasing interest on this herb drug, we undertook a thorough chemical reinvestigation of the glycosidic fraction of the methanol extract of the plant. We have already reported $^{11,12)}$ two new triterpenoid glycosides, viz. bacopasides I and II from the methanol extract of the plant. Further investigation on the extract led to the isolation of four phenylethanoid glycosides, of which the three new compounds have been designated as monnierasides I-III (1-3). The fourth one has been proved to be identical with plantainoside $\mathrm{B}^{13)}(4)$. The present paper reports the isolation and structure elucidation of three new glycosides $(\mathbf{1}-\mathbf{3})$.

\section{Results and Discussion}

The phenylethanoid glycosides $(\mathbf{1}-\mathbf{4})$ were isolated from the EtOAc soluble fraction of the methanol extract of the plant on repeated chromatography over silica gel and Diaion HP-20 followed by prep. HPLC.

The high resolution positive ion FAB mass spectrum (FAB-MS) of monnieraside I (1) showed the $[\mathrm{M}+\mathrm{H}]^{+}$ion at $\mathrm{m} / \mathrm{z} 421.1512$ corresponding to the molecular formula $\mathrm{C}_{21} \mathrm{H}_{24} \mathrm{O}_{9}$. Its ${ }^{13} \mathrm{C}$-NMR spectrum (Table 1) displayed signals for 21 carbons of which six carbons resonating between $\delta$ 62.6 and 102.3 must be due to a sugar moiety. Of the remaining 15 carbons, 8 are due to aromatic $\mathrm{CH}$, five due to aromatic quaternary carbons and two for two $\mathrm{CH}_{2}$ carbons one being attached to an oxygen function. The ${ }^{1} \mathrm{H}-\mathrm{NMR}$ spectrum of the compound exhibited four two-proton doublets in the aromatic region at $\delta 6.49,6.85,6.89$ and 7.90 , signals for two $\mathrm{CH}_{2}$ groups at $\delta 2.65 \mathrm{ddd}(2 \mathrm{H}), 3.62 \mathrm{~m}$ and $4.01 \mathrm{ddd}$ (1H each), besides signals for protons of a sugar moiety (Table 2).

The ${ }^{1} \mathrm{H}-{ }^{1} \mathrm{H}$ correlation spectroscopy (COSY) spectrum of the compound showed four sets of vicinal correlations as follows:

(i ) $\delta 2.65\left(\mathrm{H}_{2}-\beta\right)-\delta 3.62,4.01\left(\mathrm{H}_{2}-\alpha\right)$

(ii) $\delta 6.49(\mathrm{H}-3,5)-\delta 6.89(\mathrm{H}-2,6)$

(iii) $\delta 6.85\left(\mathrm{H}-3^{\prime \prime}, 5^{\prime \prime}\right)-\delta 7.90\left(\mathrm{H}-2^{\prime \prime}, 6^{\prime \prime}\right)$ (iv) $\delta 4.58\left(\mathrm{H}^{\prime} 1^{\prime}\right)-\delta 4.92\left(\mathrm{H}-2^{\prime}\right)-\delta 3.65\left(\mathrm{H}-3^{\prime}\right)-\delta$ $3.43\left(\mathrm{H}-4^{\prime}\right)-\delta 3.36\left(\mathrm{H}-5^{\prime}\right)-\delta 3.73,3.90\left(\mathrm{H}_{2}-6^{\prime}\right)$

The above correlations indicated that the compound contains one $-\mathrm{CH}_{2}-\mathrm{CH}_{2}-\mathrm{O}-$ grouping, two 1,4-disubstituted benzene rings and a hexose sugar unit.

Having thus established the ${ }^{1} \mathrm{H}$ chemical shifts (Table 2) of the compound, the corresponding ${ }^{13} \mathrm{C}$ chemical shifts (Table 1) could be easily determined from its heteronuclear multiple quantum coherence (HMQC) spectrum. The ${ }^{13} \mathrm{C}$-chemical shifts of the carbons of the sugar unit demonstrated that it must be glucose. The presence of a glucose unit in the molecule was confirmed by paper chromatography and HPLC of acid hydrolysate of $\mathbf{1}$. The total structure of the compound could, however, be elucidated on the basis of two and threebond ${ }^{1} \mathrm{H}-{ }^{13} \mathrm{C}$ correlations observed in its heteronuclear multiple bond correlation (HMBC) spectrum. Thus, the correlations of $\mathrm{H}_{2}-\alpha(\delta 3.62,4.01), \mathrm{H}_{2}-\beta(\delta 2.65), \mathrm{H}-2,6(\delta 6.89)$ and $\mathrm{H}-3,5$ ( $\delta 6.49)$ proton signals with those of the neighbouring carbons clearly revealed the presence of 4-hydroxyphenylethyl alcohol moiety as the aglycone linked to the glucose unit through $\mathrm{C}-\alpha$ of the aglycone. This was also supported by the three-bond correlation observed between the anomeric proton signal $\left(\delta 4.58, \mathrm{H}^{-1} 1^{\prime}\right)$ and $\mathrm{C}-\alpha(\delta 71.8)$ of the 4-hydroxyphenylethyl moiety. On the other hand, the correlations observed for $\mathrm{H}-2^{\prime \prime}, 6^{\prime \prime}(\delta 7.90)$ and $\mathrm{H}-3^{\prime \prime}, 5^{\prime \prime}(\delta$ 6.85) signals indicated that an $O$-4-hydroxybenzoyl group is present in the molecule. That the $O$-benzoyl group is attached to $\mathrm{C}-2^{\prime}$ of the glucose unit became evident from the three-bond correlation observed between $\mathrm{H}-2^{\prime}(\delta$ 4.92) proton signal and the signal of the ester carbonyl carbon $\left(\delta 167.4, \mathrm{C}-\alpha^{\prime \prime}\right)$. The presence of an aromatic ester was also demonstrated by the strong IR absorptions at 1690 (O-CO-Ar) and 1600 (Ar) $\mathrm{cm}^{-1}$

Based on the above evidence, monnieraside I could be represented as $\alpha-O$-[2-O-(4-hydroxybenzoyl)- $\beta$-D-glucopyranosyl]-4-hydroxyphenylethanol (1).

The high resolution positive ion FAB-MS of the monnieraside II (2) showed the $[\mathrm{M}+\mathrm{H}]^{+}$at $m / z 493.1760$ corresponding to the molecular formula $\mathrm{C}_{24} \mathrm{H}_{28} \mathrm{O}_{11}$. Its ${ }^{13} \mathrm{C}-\mathrm{NMR}$ spectrum (Table 1) displayed signals for 24 carbons, of which six carbons resonating at $\delta 102.3(\mathrm{CH}), 75.2(\mathrm{CH}), 76.2(\mathrm{CH})$, $71.7(\mathrm{CH}), 78.0(\mathrm{CH})$ and $62.6\left(\mathrm{CH}_{2}\right)$ were assigned to a glucose unit as in $\mathbf{1}$. Of the remaining carbons, two [ $\delta 36.5$ $\left(\mathrm{CH}_{2}\right)$ and $\left.71.8\left(\mathrm{CH}_{2}\right)\right]$ were present as $-\mathrm{CH}_{2}-\mathrm{CH}_{2}-\mathrm{O}-$ grouping, one as an OMe group $(\delta 56.4)$ and one as a conju- 
gated ester $\mathrm{C}=\mathrm{O}$ carbon ( $\delta$ 168.4) indicating that $\mathbf{2}$ must have a similar structure as $\mathbf{1}$ with the exception that the aglycone and the ester moieties are different. The ${ }^{1} \mathrm{H}-\mathrm{NMR}$ spectrum (Table 2) of the compound exhibited a pair of mutually coupled doublets at $\delta 6.37\left(\mathrm{H}-\beta^{\prime \prime}\right)$ and $7.63\left(\mathrm{H}-\gamma^{\prime \prime}\right)$ with $J=16.0 \mathrm{~Hz}$ indicating that the compound is a trans cinnamoyl ester. Finally, the total structure of the compound could be elucidated from its HMBC correlation data as in the sequel.

Two and three-bond correlations of the proton signals at $\delta$ 3.64, $4.01\left(\mathrm{H}_{2}-\alpha\right), 2.67\left(\mathrm{H}_{2}-\beta\right), 6.61(\mathrm{H}-2), 6.58(\mathrm{H}-5)$ and 6.48 (H-6) with those of the neighbouring carbons indicated that the aglycone moiety is a 3,4-dihydroxyphenylethyl alcohol and it is attached to the glucose unit through its $\mathrm{C}-\alpha(\delta$ 71.8) carbon atom. Again, the correlations of the proton signals at $\delta 6.37\left(\mathrm{H}-\beta^{\prime \prime}\right), 7.63\left(\mathrm{H}-\gamma^{\prime \prime}\right), 7.20\left(\mathrm{H}-2^{\prime \prime}\right), 6.81\left(\mathrm{H}-5^{\prime \prime}\right)$ and 7.09 (H-6") demonstrated that the ester group must be either 3-methoxy-4-hydroxycinnamoyl or 3-hydroxy-4methoxy-cinnamoyl. That it is 3-methoxy-4-hydroxy-cin-

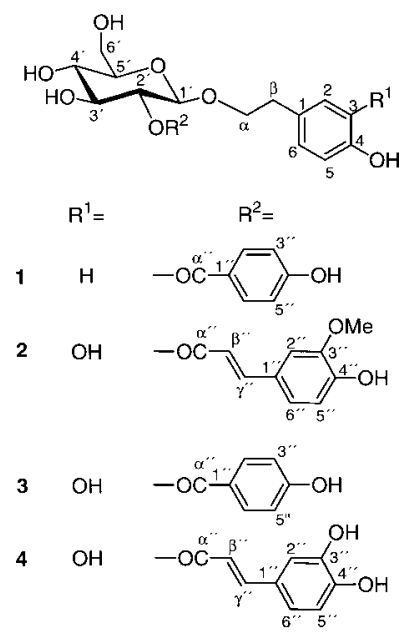

Fig. 1. Phenylethanoid Glycosides from B. monniera namoyl group was evident from the substantial NOE observed for the OMe proton signal on irradiation of the $\mathrm{H}-2^{\prime \prime}$ signal. Moreover, the three-bond correlation of the $\mathrm{H}-2^{\prime}$ proton signal $(\delta 4.82)$ of the glucose unit with the ester $\mathrm{C}=\mathrm{O}$ carbon ( $\left.\delta 168.4, \mathrm{C}-\alpha^{\prime \prime}\right)$ clearly revealed that the cinnamoyl ester group is attached to $\mathrm{C}-2^{\prime}$ of glucose. Monnieraside II was, therefore, represented as $\alpha-O-[2-O-(3-m e t h o x y-4-h y-$ droxycinnamoyl)- $\beta$-D-glucopyranosyl]-3,4-dihydroxyphenylethanol (2).

The high resolution positive ion FAB-MS of monnieraside

Table 1. ${ }^{13} \mathrm{C}$ Chemical Shifts ${ }^{a}$ of $\left(\boldsymbol{\delta}, \mathrm{CD}_{3} \mathrm{OD}, 125 \mathrm{MHz}\right)$ of $\mathbf{1}-\mathbf{4}$

\begin{tabular}{|c|c|c|c|c|}
\hline Carbon & 1 & 2 & 3 & 4 \\
\hline $\mathrm{C}-1$ & 130.9 & 131.5 & 131.4 & 131.5 \\
\hline C-2 & 130.8 & 117.1 & 116.9 & 117.0 \\
\hline $\mathrm{C}-3$ & 115.9 & 145.9 & 145.9 & 145.9 \\
\hline C-4 & 156.5 & 144.5 & 144.5 & 144.5 \\
\hline C-5 & 115.9 & 116.2 & 116.2 & 116.2 \\
\hline C-6 & 130.8 & 121.3 & 121.2 & 121.3 \\
\hline $\mathrm{C}-\alpha$ & 71.8 & 71.8 & 71.9 & 71.8 \\
\hline $\mathrm{C}-\beta$ & 36.2 & 36.5 & 36.5 & 36.5 \\
\hline $\mathrm{C}-1^{\prime}$ & 102.3 & 102.3 & 102.4 & 102.3 \\
\hline $\mathrm{C}-2^{\prime}$ & 75.4 & 75.2 & 75.5 & 75.2 \\
\hline C- $-3^{\prime}$ & 76.2 & 76.2 & 76.3 & 76.2 \\
\hline C- $4^{\prime}$ & 71.8 & 71.7 & 71.8 & 71.7 \\
\hline $\mathrm{C}-5^{\prime}$ & 78.1 & 78.0 & 78.1 & 78.0 \\
\hline C- $6^{\prime}$ & 62.6 & 62.6 & 62.7 & 62.6 \\
\hline $\mathrm{C}-1^{\prime \prime}$ & 122.4 & 127.8 & 122.3 & 127.8 \\
\hline $\mathrm{C}-2^{\prime \prime}$ & 133.0 & 111.8 & 133.0 & 115.2 \\
\hline $\mathrm{C}-3^{\prime \prime}$ & 116.1 & 149.3 & 116.2 & 146.7 \\
\hline $\mathrm{C}-4^{\prime \prime}$ & 163.5 & 150.5 & 163.7 & 149.5 \\
\hline $\mathrm{C}-5^{\prime \prime}$ & 116.1 & 116.4 & 116.2 & 116.5 \\
\hline C-6" & 133.0 & 124.1 & 133.0 & 123.0 \\
\hline $\mathrm{C}-\alpha^{\prime \prime}$ & 167.4 & 168.4 & 167.5 & 168.4 \\
\hline C- $\beta^{\prime \prime}$ & - & 115.6 & - & 115.2 \\
\hline $\mathrm{C}-\gamma^{\prime \prime}$ & - & 147.0 & - & 147.0 \\
\hline $\mathrm{OMe}$ & - & 56.4 & - & - \\
\hline
\end{tabular}

a) Chemical shifts were assigned on the basis of $2 \mathrm{D}$ NMR, viz. ${ }^{1} \mathrm{H}-{ }^{1} \mathrm{H}$ COSY, HMQC, HMBC and NOESY spectral analyses.

Table 2. ${ }^{1} \mathrm{H}$ Chemical $\left.\operatorname{Shifts}^{a}\right)\left(\delta, \mathrm{CD}_{3} \mathrm{OD}, 500 \mathrm{MHz}\right)$ of $\mathbf{1}-\mathbf{4}$

\begin{tabular}{|c|c|c|c|c|}
\hline Proton & 1 & 2 & 3 & 4 \\
\hline $\mathrm{H}-2$ & $6.89 \mathrm{~d}(8.6)$ & $6.61 \mathrm{~d}(2.0)$ & $6.54 \mathrm{~d}(2.0)$ & $6.52 \mathrm{~d}(2.1)$ \\
\hline $\mathrm{H}-3$ & $6.49 \mathrm{~d}(8.6)$ & - & - & - \\
\hline H-5 & $6.49 \mathrm{~d}(8.6)$ & $6.58 \mathrm{~d}(8.0)$ & $6.46 \mathrm{~d}(8.0)$ & $6.50 \mathrm{~d}(8.1)$ \\
\hline H-6 & $6.89 \mathrm{~d}(8.6)$ & $6.48 \mathrm{dd}(8.0,2.0)$ & $6.39 \mathrm{dd}(8.0,2.0)$ & $6.39 \mathrm{dd}(8.1,2.1)$ \\
\hline $\mathrm{H}_{2}-\alpha$ & $\begin{array}{l}3.62 \mathrm{~m} \text {, } \\
4.01 \mathrm{ddd}(9.8,6.5,6.5)\end{array}$ & $\begin{array}{l}3.64 \text { ddd }(9.5,7.0,7.0) \\
4.01 \text { ddd }(9.5,7.0,7.0)\end{array}$ & $\begin{array}{l}3.63 \mathrm{~m} \text {, } \\
3.97 \mathrm{ddd}(9.8,7.3,7.3)\end{array}$ & $\begin{array}{l}3.55 \text { ddd }(9.8,7.3,7.3) \text {, } \\
3.91 \text { ddd }(9.8,7.0,7.0)\end{array}$ \\
\hline $\mathrm{H}_{2}-\beta$ & 2.65 ddd $(6.5,6.5,1.8)$ & $2.67 \mathrm{dd}(7.0,7.0)$ & $2.60 \mathrm{dd}(7.3,7.3)$ & $2.58 \mathrm{dd}(7.0,7.0)$ \\
\hline $\mathrm{H}-1^{\prime}$ & $4.58 \mathrm{~d}(8.0)$ & $4.51 \mathrm{~d}(8.0)$ & $4.58 \mathrm{~d}(8.1)$ & $4.42 \mathrm{~d}(7.9)$ \\
\hline $\mathrm{H}-2^{\prime}$ & $4.92 \mathrm{dd}(9.6,8.0)$ & $4.82 \mathrm{dd}(9.5,8.0)$ & $4.90 \mathrm{~m}$ & $4.73 \mathrm{dd}(9.3,7.9)$ \\
\hline $\mathrm{H}-3^{\prime}$ & $3.65 \mathrm{~m}$ & $3.58 \mathrm{dd}(9.5,9.5)$ & $3.63 \mathrm{~m}$ & $3.48 \mathrm{dd}(9.3,9.3)$ \\
\hline $\mathrm{H}-4^{\prime}$ & $3.43 \mathrm{dd}(9.2,9.2)$ & $3.40 \mathrm{dd}(9.5,9.5)$ & $3.41 \mathrm{dd}(9.3,9.3)$ & $3.30 \mathrm{dd}(9.3,9.3)$ \\
\hline $\mathrm{H}-5^{\prime}$ & $3.36 \mathrm{dd}(5.6,1.9)$ & $3.33 \mathrm{~m}$ & $3.36 \mathrm{~m}$ & $3.23 \mathrm{~m}$ \\
\hline $\mathrm{H}_{2}-6^{\prime}$ & $\begin{array}{l}3.73 \mathrm{dd}(12.0,5.6) \\
3.90 \mathrm{dd}(12.0,1.9)\end{array}$ & $\begin{array}{l}3.70 \mathrm{dd}(12.2,5.7), \\
3.88 \mathrm{~m}\end{array}$ & $\begin{array}{l}3.71 \mathrm{dd}(11.7,5.8), \\
3.89 \mathrm{dd}(11.7,2.0)\end{array}$ & $\begin{array}{l}3.61 \mathrm{dd}(11.9,5.8), \\
3.80 \mathrm{dd}(11.9,2.1)\end{array}$ \\
\hline $\mathrm{H}-2^{\prime \prime}$ & $7.90 \mathrm{~d}(8.5)$ & $7.20 \mathrm{~d}(2.0)$ & $7.89 \mathrm{~d}(8.5)$ & $6.98 \mathrm{~d}(1.8)$ \\
\hline $\mathrm{H}-3^{\prime \prime}$ & $6.85 \mathrm{~d}(8.5)$ & - & $6.83 \mathrm{~d}(8.5)$ & - \\
\hline $\mathrm{H}-5^{\prime \prime}$ & $6.85 \mathrm{~d}(8.5)$ & $6.81 \mathrm{~d}(8.2)$ & $6.83 \mathrm{~d}(8.5)$ & $6.70 \mathrm{~d}(8.2)$ \\
\hline $\mathrm{H}-6^{\prime \prime}$ & $7.90 \mathrm{~d}(8.5)$ & $7.09 \mathrm{dd}(8.2,2.0)$ & $7.89 \mathrm{~d}(8.5)$ & $6.88 \mathrm{dd}(8.2,1.8)$ \\
\hline $\mathrm{H}_{3}-3^{\prime \prime}$ & - & $3.90 \mathrm{~s}$ & - & - \\
\hline $\mathrm{H}-\beta^{\prime \prime}$ & - & $6.37 \mathrm{~d}(16.0)$ & - & $6.20 \mathrm{~d}(15.8)$ \\
\hline $\mathrm{H}-\gamma^{\prime \prime}$ & - & $7.63 \mathrm{~d}(16.0)$ & - & $7.48 \mathrm{~d}(15.8)$ \\
\hline
\end{tabular}

a) Chemical shifts were assigned on the basis of $2 \mathrm{D}$ NMR, viz. ${ }^{1} \mathrm{H}-{ }^{1} \mathrm{H}$ COSY, HMQC, HMBC, and NOESY spectral analyses. Figures in the parentheses are the coupling constants in $\mathrm{Hz}$. 
III (3) showed the $[\mathrm{M}+\mathrm{H}]^{+}$at $m / z 437.1439$ corresponding to the molecular formula $\mathrm{C}_{21} \mathrm{H}_{24} \mathrm{O}_{10}$ which is one oxygen atom more than that of monnieraside I (1). A comparison of its ${ }^{13} \mathrm{C}$ chemical shifts with those of $\mathbf{1}$ (Table 1) revealed that the aglycone moiety of $\mathbf{3}$ must have two phenolic $\mathrm{OH}$ groups as against one in that of 1 . Its ${ }^{1} \mathrm{H}-\mathrm{NMR}$ spectrum (Table 2) displayed two ortho coupled signals at $\delta 6.39$ (dd, $J=8.0$, $2.0 \mathrm{~Hz}, \mathrm{H}-6)$ and $6.46(\mathrm{~d}, J=8.0 \mathrm{~Hz}, \mathrm{H}-5)$, the former being also meta coupled to another proton resonating at $\delta 6.54$ (d, $J=2.0 \mathrm{~Hz}, \mathrm{H}-2)$. It was therefore assumed that the aglycone of 3 must be 3,4-dihydroxyphenylethanol. The HMBC data of the compound also fully corroborated the above assumption.

Monnieraside III was, therefore, represented as $\alpha-O-[2-O$ (4-hydroxybenzoyl)- $\beta$-D-glucopyranosyl]-3,4-dihydroxyphenylethanol (3).

\section{Experimental}

Optical rotations were measured in $\mathrm{MeOH}$ solutions. IR spectra were recorded using $\mathrm{KBr}$ discs. 1D and 2D NMR spectra were recorded on 500 and $600 \mathrm{MHz}$ instruments in pyridine- $d_{5}$ with tetramethylsilane as an internal standard. FAB-MS were recorded using nitrobenzylalcohol as the matrix. HPLC was performed on a $\mathrm{C}_{18}$ column $(5 \mu, 8 \mathrm{~mm}$ i.d. $\times 250 \mathrm{~mm}$, detector, RI) with $\mathrm{H}_{2} \mathrm{O}-\mathrm{MeCN}(9: 1)$ as the mobile phase.

Plant Material The aerial parts of Bacopa monniera collected during May - June were supplied by M/s United Chemicals and Allied Products, 10, Clive Row, Kolkata-700001, India and a voucher specimen is available in the herbarium of the company.

Extraction and Isolation of Compounds The air-dried and powdered aerial parts of Bacopa monniera $(4.4 \mathrm{~kg}$ ) were defatted with petroleum ether (bp $60-80^{\circ} \mathrm{C}$ ) in a soxhlet apparatus. The defatted material was then extracted three times with $\mathrm{MeOH}$ in a percolator at room temp. The combined $\mathrm{MeOH}$ extract was concentrated and kept over night at room temp. and filtered.

The filtrate was diluted with water and shaken in a separating funnel with EtOAc $(250 \mathrm{ml} \times 8)$. The combined EtOAc extract on removal of the solvent yielded a gummy material $(20 \mathrm{gm})$ which was subjected to column chromatography $(\mathrm{CC})$ over silica gel. On elution with $\mathrm{CHCl}_{3}-\mathrm{MeOH}(9: 1$ and $8: 2$ ) yielded a gummy material containing 1 and 2 (fr. A), while further elution with $\mathrm{CHCl}_{3}-\mathrm{MeOH}(7: 3$ and $6: 4$ ) afforded a mixture of $\mathbf{3}$ and $\mathbf{4}$ (fr. B). Both the fractions were separately chromatographed over Diaion HP-20 and eluted respectively with $\mathrm{MeOH}-\mathrm{H}_{2} \mathrm{O}(1: 1$ and $1: 3)$. The residues obtained from frs. A and B were further purified by prep. HPLC using $\mathrm{H}_{2} \mathrm{O}-\mathrm{MeCN}$ $(9: 1)$ as the mobile phase to yield pure $\mathbf{1}(30 \mathrm{mg}), \mathbf{2}(21 \mathrm{mg}), \mathbf{3}(12 \mathrm{mg})$ and $4(32 \mathrm{mg})$.

Monnieraside I (1): Amorphous, $[\alpha]_{\mathrm{D}}^{23}-14^{\circ}(c=0.8, \mathrm{MeOH})$. IR $v_{\max }^{\mathrm{KBr}}$ $\mathrm{cm}^{-1}: 3350(\mathrm{OH}), 1690(-\mathrm{O}-\mathrm{CO}-\mathrm{Ar}), 1600$ (Aromatic). High resolution (HR)-FAB-MS (positive) $m / z: 421.1512[\mathrm{M}+\mathrm{H}]^{+}$. Calcd for $\left[\mathrm{C}_{21} \mathrm{H}_{24} \mathrm{O}_{9}+\right.$ $\mathrm{H}]^{+}:$421.1497. ${ }^{13} \mathrm{C}-\mathrm{NMR}$ : Table 1. ${ }^{1} \mathrm{H}-\mathrm{NMR}$ : Table 2.

Monnieraside II (2): Amorphous, $[\alpha]_{\mathrm{D}}^{23}-8^{\circ},(c=0.7, \mathrm{MeOH})$. IR $v_{\max }^{\mathrm{KBr}}$ $\mathrm{cm}^{-1}: 3350(\mathrm{OH}), 1690(-\mathrm{O}-\mathrm{CO}-\mathrm{Ar}), 1600$ (Aromatic). HR-FAB-MS (positive) $m / z: 493.1706[\mathrm{M}+\mathrm{H}]^{+}$. Calcd for $\left[\mathrm{C}_{24} \mathrm{H}_{28} \mathrm{O}_{11}+\mathrm{H}\right]^{+}: 493.1708 .{ }^{13} \mathrm{C}-$ NMR: Table $1,{ }^{1}$ H-NMR: Table 2.

Monnieraside III (3): Amorphous, $[\alpha]_{\mathrm{D}}^{23}-3^{\circ},(c=0.3, \mathrm{MeOH})$. IR $v_{\max }^{\mathrm{KBr}}$ $\mathrm{cm}^{-1}: 3400(\mathrm{OH}), 1690$ (-O-CO-Ar), 1600 (Aromatic). HR-FAB-MS (positive) $m / z: 437.1439[\mathrm{M}+\mathrm{H}]^{+}$. Calcd for $\left(\mathrm{C}_{21} \mathrm{H}_{24} \mathrm{O}_{10}+\mathrm{H}\right]^{+}: 437.1446 .{ }^{13} \mathrm{C}-$ NMR: Table $1,{ }^{1} \mathrm{H}-\mathrm{NMR}$ : Table 2.

Plantaionoside B (4): Amorphous, HR-FAB-MS (positive) $m / z$ : 479.1551 $[\mathrm{M}+\mathrm{H}]^{+}$. Calcd for $\left.\left[\mathrm{C}_{23} \mathrm{H}_{26} \mathrm{O}_{11}+\mathrm{H}\right]\right]^{+}:$479.1552. ${ }^{13} \mathrm{C}-\mathrm{NMR}$ : Table $1 .{ }^{1} \mathrm{H}-$ NMR: Table $2 .{ }^{13} \mathrm{C}-\mathrm{NMR}$ data were found to be almost identical to those reported. ${ }^{12)}$

Hydrolysis of 1-3 Compounds 1 (4 mg), $2(5 \mathrm{mg})$ and $3(2 \mathrm{mg})$ were dissolved separately in $1 \% \mathrm{H}_{2} \mathrm{SO}_{4}$ in $\mathrm{H}_{2} \mathrm{O}(4 \mathrm{ml}$ each $)$ and refluxed for $1 \mathrm{~h}$. The resulting reaction mixtures were neutralized with $\mathrm{NaHCO}_{3}$, passed through Bond Elut $\mathrm{C}_{18}$ and were evaporated to dryness in vacuo. The residues were triturated with $\mathrm{MeOH}$ and the $\mathrm{MeOH}$ solution was evaporated. The residues were dissolved in $\mathrm{H}_{2} \mathrm{O}-\mathrm{MeCN}(1: 2)$ and subjected to HPLC analysis using Waters carbohydrate column $(4.6 \mathrm{~mm} \times 250 \mathrm{~mm})$ and $\mathrm{H}_{2} \mathrm{O}-$ $\operatorname{MeCN}(1: 4)$ as the mobile phase. Co-injection of the samples with glucose showed single peaks at retention time of $3.7 \mathrm{~min}$ in all the three cases.

\section{References}

1) Chopra R. N., Chopra I. C., Verma B. S., "Glossary of Indian Medicinal Plants," CSIR, New Delhi, 1969.

2) Singh H. K., Dhawan B. N., Indian J. Pharmacol., 10, $72-72$ (1978).

3) Singh H. K., Dhawan B. N., J. Ethnopharmacol., 5, 205-214 (1982).

4) Singh H. K., Rastogi R. P., Srimal R. C., Dhawan B. N., Phytother. Res., 2, 70-75 (1988).

5) Jain P., Kulshrestha D. K., Phytochemistry, 33, 449—451 (1993).

6) Rastogi S., Pal R., Kulshrestha D. K., Phytochemistry, 36, 133-137 (1994).

7) Rastogi S., Kulshrestha D. K., Indian J. Chem., 38B, 353-356 (1998).

8) Garai S., Mahato S. B., Ohtani K., Yamasaki K., Phytochemistry, 42, 815 -820 (1996).

9) Garai S., Mahato S. B., Ohtani K., Yamasaki K., Phytochemistry, 43, 447-449 (1996).

10) Mahato S. B., Garai S., Chakravarty A. K., Phytochemistry, 53, 711714 (2000).

11) Chakravarty A. K., Sarkar T., Masuda K., Shiojima K., Nakane T., Kawahara N., Phytochemistry, 58, 553-556 (2001).

12) Chakravarty A. K., Sarkar T., Masuda K., Shiojima K., Nakane T., Kawahara N., Phytochemistry, 59, 365-365 (2002).

13) Miyase T., Ishino M., Akahori C., Ueno A., Ohkawa Y., Tanizawa H., Phytochemistry, 30, 2015-2018 (1991). 